\title{
Awareness on Dementia in the Context of Bangladesh
}

\author{
Fatema Zohra* and Md Monoarul Haque \\ Department of Psychiatry, Bangabandhu Sheikh Mujib Medical University, Bangladesh
}

Submission: April 18, 2018; Published: April 25, 2018

*Corresponding author: Fatema Zohra, Department of Psychiatry, Bangabandhu Sheikh Mujib Medical University, Bangladesh,

Email: bjnd18@gmail.com

\section{Editorial}

Dementia is a burning and challenging public health issue not only in the different part of the globe but also in developing country like Bangladesh now which has social as well as economic burden and has negative effects on other family members or caregivers. As geriatric people are increasing due to improvement of health care access and quality of life, chance of developing dementia is also increasing along with ageing. It is projected that within 2050 number of aged people will be $21 \%$ i.e. one in every five will be geriatric people. Actually older people are vulnerable; they can break with a mild force. This is why they need extra care, support from family members and peaceful environment. According to Alzheimer Society of Bangladesh, number of dementia patients is 4,60,000 in 2015 in Bangladesh but no recent data is available. They also stated that though WHO has given first line priority to dementia treatment and care but still our government did not mention it as a health care problem at all. Moreover we need evidence based care considering context of our country by utilizing our local resources. It is always accepted that awareness and knowledge

building are key to combat any public health strategy. As burden of dementia is huge, so we have to give priority on prevention in order to minimize risk/complication. In our day to day observation we found that awareness and knowledge regarding dementia among the people of Bangladesh is poor and in some spheres no knowledge at all. Even patients of dementia do not get accurate care irrespective to age, gender, socioeconomic class, which ultimately leads to isolated from the society due to existing stigma and taboos. Gradually peer groups become disappointed. As a result, we are going to face a big challenge and everybody particularly policy maker should think about this issue and make a comprehensive plan to deal dementia and its consequences. According to World Alzheimer Report 2011, we came to know that as earlier diagnosis and early intervention are considered as important mechanisms for dementia, we have to build up trained medical personnel, specialized hospital specifically designed for dementia, research wing and at last but not least public health workers with support services so that burden of dementia patients will reduce.

This work is licensed under Creative Commons Attribution 4.0 License DOI:10.19080/JOJPH.2018.03.555613

\section{Your next submission with Juniper Publishers will reach you the below assets}

- Quality Editorial service

- Swift Peer Review

- Reprints availability

- E-prints Service

- Manuscript Podcast for convenient understanding

- Global attainment for your research

- Manuscript accessibility in different formats

( Pdf, E-pub, Full Text, Audio)

- Unceasing customer service

Track the below URL for one-step submission https://juniperpublishers.com/online-submission.php 